\title{
PENGEMBANGAN BAHAN AJAR PROGRAM LINEAR BERBASIS KONTEKSTUAL DAN ICT
}

\author{
Swaditya Rizki ${ }^{1)}$, Nego Linuhung ${ }^{2)}$ \\ ${ }^{1), 2)}$ Pendidikan Matematika FKIP Universitas Muhammadiyah Metro \\ swaditya.rizki@gmail.com ${ }^{1)}$,nego_mtk@yahoo.co.id ${ }^{2)}$
}

\begin{abstract}
This study is a research and development $(R \& D)$. The model used in this research is to adapt the development of the 4D model (Define, Design, Develop, Disseminate) developed by Thiagarajan. This study aims to generate the teaching materials based contextual and ICT are good at program linear and to determine the effectiveness of teaching materials based contextual and ICT at program linear on learning outcomes. Data collection instruments used in this study in the form of questionnaires, interviews, sheet validation, and matter. Data analysis techniques used in this research and development is a qualitative descriptive analysis technique to calculate the average, while for influence before and after treatment that uses the analysis of paired sample $t$ test. The conclusions obtained from the development are teaching materials based contextual and ICT are very valid and practical for use in the learning process. From the test results, it can be concluded that there is a very significant influence mathematics teaching materials based contextual and ICT on student learning outcomes. So, teaching materials based contextual and ICT is very effective for use in learning the material Program Linear.
\end{abstract}

Keywords: Research and Development (R\&D), Teaching Materials, Program Linear, Contextual and ICT

\section{PENDAHULUAN}

Bahan ajar merupakan salah satu perangkat/bahan dalam proses pembelajaran yang sangat membantu siswa ataupun pembaca dalam memahami materi tertentu. Bahan ajar yang baik tentu selain harus menarik dari segi tampilan maupun konten, maka harus sesuai dengan kebutuhan siswa terhadap materi yang dipelajarinya. Darmadi (2009:212) yang menyatakan bahwa bahan ajar atau materi pembelajaran (instructional materials) secara garis besar terdiri dari pengetahuan, ketrampilan, dan sikap yang harus dipelajari siswa dalam rangka mencapai standar kompetensi yang telah ditentukan.

Bahan ajar yang baik harus melalui validasi ahli, praktis dalam memahaminya, dan efektif untuk proses pembelajaran. Menurut Mudlofir (2011:128) bahan ajar merupakan segala bentuk bahan yang digunakan untuk membantu dalam proses pembelajaran. Bahan tersebut disusun dengan runtut dan sistematis baik tertulis maupun tidak tertulis.

Masih menurut Mudlofir (2011:130) ada beberapa prinsip dalam bahan ajar yang dikemukakan yaitu menimbulkan minat baca, ditulis dan dirancang untuk siswa, menjelaskan tujuan instruksional, disusun berdasarkan pola belajar yang fleksibel, struktur berdasarkan kebutuhan siswa dan kompetensi akhir yang akan dicapai, memberikan kesempatan pada siswa untuk berlatih, mengakomodasi kesulitan siswa, memberi rangkuman, 
gaya penulisan komunikatif dan semi formal, kepadatan berdasarkan kebutuhan siswa.

Namun faktanya buku-buku yang ada belum mengintegrasikan materi ajar dengan media komputer. Selain itu materi yang ada pun kebanyakan belum berbasis kontekstual atau mengaitkan dengan dunia nyata, sehingga pembelajaran matematika dianggap sebagian peserta didik merupakan pelajaran yang sulit. Hal ini disebabkan banyak faktor, misalnya rendahnya tingkat belajar peserta didik untuk mempelajari matematika, bisa juga dikarenakan materinya yang dianggap sulit atau bahkan dari bahan ajarnya yang membuat sulit peserta didik.

Dari permasalahan tersebut yang akan diprioritaskan yaitu pada materi program linear. Karena banyak peserta didik yang masih kesulitan dengan materi ini, padahal secara konsep materi ini sangatlah mudah. Berdasarkan hasil wawancara dengan guru mata pelajaran bahwa pada materi program linier, kebanyakan siswa sulit untuk memahami konsep memodelkan masalah dari materi tersebut. Dari contoh yang diberikan, siswa masih bingung bagaimana cara menentukan variabel dari soal dan cara menyelesaikannya khususnya dalam menggambar grafik dan mencari daerah hasilnya. Bahan ajar yang adapun tidak menjelaskan detail pokok permasalahan dan kebanyakan guru belum memanfaatkan media berbasis ICT.

Di samping itu materi dan contoh yang ada masih terlalu abstrak dan tidak mengarahkan siswa untuk mengaplikasikan keranah kontekstual, Baharuddin dan Wahyuni (2008:137) yang menyatakan bahwa pembelajaran kontekstual (Contextual Teaching Learning) adalah suatu konsep belajar yang dapat membantu guru mengaitkan materi pembelajaran dengan dunia nyata dan membuat siswa mengetahui hubungan antara pengetahuan yang dimiliki dengan penerapan kehidupannya sehari-hari. Selain itu, Korucu and Gunduz (2011) yang mengatakan bahwa "dalam pencapaian akademik yang menerima pembelajaran berbantuan komputer akan lebih tinggi dibandingkan dengan metode tradisional".

Berdasarkan permasalahan ini yang menjadi dasar untuk melakukan penelitian pengembangan bahan ajar berbasis kontekstual dan ICT (Information and Communication Technology). Dengan harapan bahwa bahan ajar yang berbasis kontekstual dan ICT serta peran guru/dosen dalam proses pembelajaran menyebabkan siswa menjadi senang dan lebih mudah dalam memahami materi. Hal ini seperti yang dinyatakan oleh beberapa peneliti yang menyatakan bahwa pembelajaran berbasis kontekstual akan memudahkan siswa dalam memahami konsep materi, bukan hanya teori yang berbentuk rumus dan tidak tahu kegunaannya.

Dari latar belakang masalah yang ada, maka tujuan penelitian ini adalah 1) Mendeskripsikan kondisi bahan ajar dan media yang ada saat ini pada materi program linear; 2) Menghasilkan bahan ajar berbasis kontekstual yang baik pada materi program linear; 3) Menghasilkan media pembelajaran berbasis ICT yang baik pada materi program linear; 4) Mengetahui efektifitas bahan ajar berbasis kontekstual dan media ICT pada materi program linear terhadap hasil belajar.

\section{METODE PENELITIAN}

\begin{tabular}{|c|c|}
\hline Pada & penelitian \\
\hline ggunakan & jenis penelitian \\
\hline
\end{tabular}


e-ISSN 2442-5419 Vol. 5, No. 2 (2016) 137-144

p-ISSN 2089-8703

development (R\&D). Model yang

Semmel, dan Semmel (1974) yaitu digunakan dalam penelitian ini mengadaptasi dari model 4D yang dikembangkan oleh Thiagarajan,

Define, Design, Develop, Disseminate. Adapun bagan alir model 4D tersebut adalah sebagai berikut:

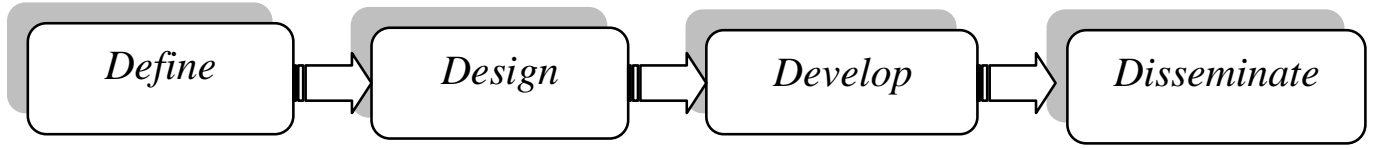

Gambar 1. Langkah-langkah Model 4D.

Adapun tahapan yang sudah dilaksanakan adalah sebagai berikut:

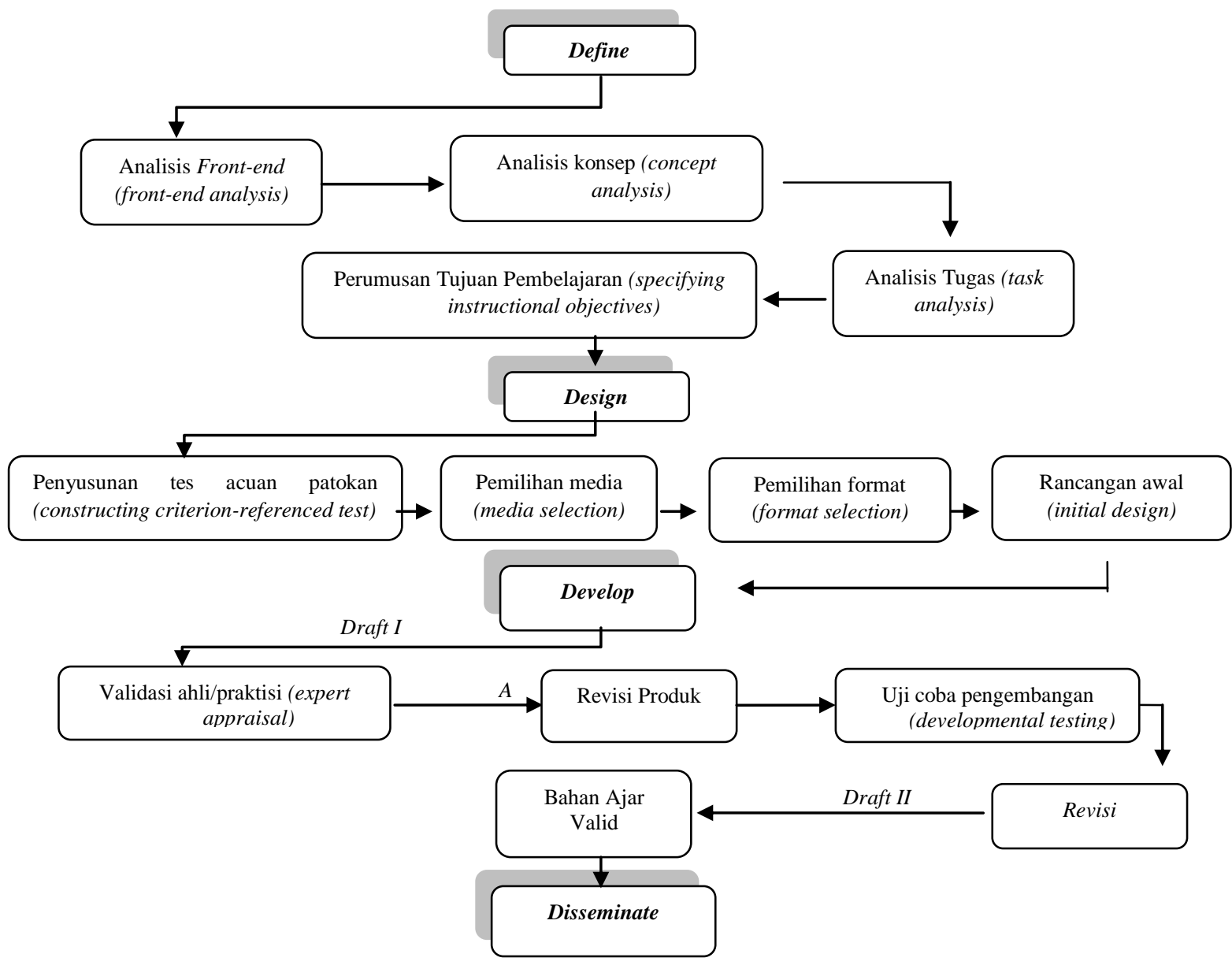

Gambar 2. Modifikasi Model Pengembangan Bahan Ajar dari Model 4D

Penelitian ini dilaksanakan di Program Studi Pendidikan Matematika Universitas Muhammadiyah Metro dan SMA Negeri 1 Punggur pada semester ganjil Tahun Akademik 2016/2017. Teknik pengumpulan data yang digunakan dalam penelitian ini adalah:
1. Wawancara digunakan untuk mengumpulkan informasi dari guru dan siswa tentang masalah-masalah dalam mempelajari materi program linear.

2. Angket digunakan untuk mengumpulkan informasi tentang 
tanggapan/penilaian dari produk yang sudah dibuat.

3. Tes digunakan untuk mengambil data eksperimen yang tujuannya mengetahui pengaruh dari produk yang dibuat terhadap hasil belajar.

Untuk mengukur kualitas perangkat pembelajaran yang baik harus memenuhi kriteria kevalidan, kepraktisan, dan keefektifan. Dalam penelitian ini akan diuji validitas untuk bahan ajar dan media ICT dari segi format, bahasa dan isi. Untuk kepraktisan sendiri harus memenuhi kriteria sesuai dengan materi dan mudah dipahami. Sedangkan untuk keefektifan akan dilakukan uji coba terhadap perangkat untuk mencari keefektifan dari produk yang dihasilkan terhadap hasil belajar.

Uji coba lapangan dilakukan 2 tahap yaitu skala kecil dan skala besar untuk memperoleh masukan langsung berupa respon, reaksi, dan komentar pelajar terhadap bahan ajar yang telah disusun. Pada tahap skala kecil dilakukan oleh 5 orang untuk mengetahui kekurangan dari produk awal. Pada tahap uji coba skala besar dengan cara eksperimen ke dalam kelompok kelas yaitu ujicoba 1 kelas dengan 2 kali pertemuan. Desain eksperimen menggunakan before-after untuk mengetahui pengaruh produk sebelum dan sesudah pemakaian produk terhadap hasil belajar. Adapun model eksperimennya digambarkan seperti gambar berikut:

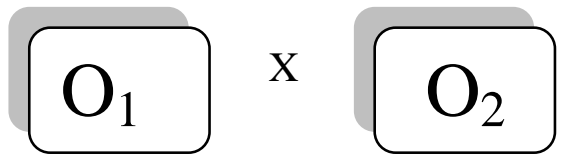

Gambar 3. Desain Eksperimen (beforeafter).

Dimana $\mathrm{O}_{1}$ adalah sebelum perlakuan dan $\mathrm{O}_{2}$ adalah sesudah perlakuan, dan $\mathrm{X}$ adalah perlakuannya yaitu penggunaan bahan ajar.

\section{HASIL PENELITIAN DAN PEMBAHASAN}

Hasil yang dicapai dalam penelitian pengembangan ini yaitu seperti pada model yang sudah diadaptasi dari dari model penelitian pengembangan yang dikembangkan oleh Thiagarajan, Semmel, dan Semmel (1974) yaitu Define, Design, Develop, Disseminate. Hasil yang dicapai tersebut dijelaskan dalam paparan di bawah ini:

\section{Tahap I: Define (Pendefinisian)}

Tahap define ini mencakup empat langkah pokok, yaitu analisis Front-end (front-end analysis), analisis konsep (concept analysis), analisis tugas (task analysis), dan perumusan tujuan pembelajaran (specifying instructional objectives).

1. Analisis Front-end (front-end analysis)

Analisis front-end dilakukan dengan cara wawancara ke guru dan siswa untuk memunculkan dan menetapkan masalah dasar yang dihadapi dalam pembelajaran. Berdasarkan analisis front-end dilakukan dengan cara wawancara ke guru dan siswa diperoleh bahwa guru menggunakan bahan ajar biasa dan tanpa ICT untuk mengajar di kelas, hal tersebut menyebabkan siswa kurang aktif dan tidak dapat mengkonstruksi pengetahuannya sendiri dan bahan ajar yang digunakan kurang mengaitkan pengetahuan pada kesidupan seharihari.

Selain itu, siswa juga tidak memiliki bahan ajar sendiri yang dapat dibawa pulang dan dipelajari sendiri. Berdasarkan analisis tersebut, diperoleh kesimpulan bahwa perlu dikembangkan suatu 
bahan ajar Program Linear berbasis kontekstual dan ICT yang dapat membuat siswa aktif siswa dan membantu siswa dalam proses mengkonstruksi pengetahuannya sendiri dengan kehidupan seharihari dan mudah dipahami karena pembelajarannya berbasis ICT.

2. Analisis konsep (concept analysis)

Analisis konsep ini dilakukan dengan cara wawancara untuk mengidentifikasi konsep pokok yang akan diajarkan, menyusunnya dalam bentuk hirarki, dan merinci konsepkonsep individu ke dalam hal yang kritis dan yang tidak relevan. Analisis konsep yang telah dilakukan adalah mengidentifikasi bagian-bagian penting dan utama yang akan dipelajari dan menyusun secara sistematis submateri yang relevan yang akan masuk pada bahan ajar berdasarkan Analisis Front-end (front-end analysis) yaitu Prasyarat, Petunjuk Penggunaan, Standar Kompetensi (SK), Kompetensi Dasar (KD), Kriteria Keberhasilan dan Peta Konsep yaitu bahan ajar Program Linear berbasis kontekstual.

3. Analisis Tugas (task analysis)

Analisis tugas ini dilakukan dengan cara wawancara yang bertujuan untuk mengidentifikasi keterampilan-keterampilan utama yang akan dikaji dan menganalisisnya kedalam himpunan keterampilan tambahan. Analisis ini memastikan ulasan yang menyeluruh tentang tugas dalam materi pembelajaran. Selanjutnya setelah Analisis konsep (concept analysis) dilanjutkan dengan analisis tugas (task analysis). Berdasarkan hasil analisis diperoleh gambaran mengenai tugas-tugas yang diperlukan dalam pembelajaran sesuai dengan standar kompetensi.

4. Perumusan Tujuan Pembelajaran (specifying instructional objectives)

Perumusan tujuan

pembelajaran yaitu merangkum hasil dari analisis konsep dan analisis tugas untuk menentukan perilaku objek penelitian. Kumpulan objek tersebut menjadi dasar untuk menyusun tes dan merancang bahan ajar yang kemudian diintegrasikan ke dalam materi bahan ajar. Berdasarkan analisis ini diperoleh tujuan-tujuan pembelajaran yang akan dicapai pada bahan ajar Program Linear berbasis kontekstual yang dikembangkan.

\section{Tahap II: Design (Perancangan)}

Pada tahap perancangan ini bertujuan untuk merancang prototipe perangkat pembelajaran untuk memperoleh draft awal. Ada empat langkah yang akan dilakukan pada tahap ini, yaitu: (1) penyusunan standar tes (criterion-test construction), (2) pemilihan media (media selection) yang sesuai dengan karakteristik materi dan tujuan pembelajaran, (3) pemilihan format (format selection), yakni mengkaji format-format bahan ajar yang ada dan menetapkan format bahan ajar yang akan dikembangkan, (4) membuat rancangan awal (initial design) sesuai format yang dipilih. Berikut adalah hasil dari tahapan-tahapan yang telah dilakukan:

1. Penyusunan tes acuan patokan (constructing criterion-referenced test)

Penyusunan tes acuan patokan merupakan langkah yang menghubungkan antara tahap 
pendefinisian (define) dengan tahap perancangan (design). Hasil Analisis Penyusunan tes acuan patokan diperoleh:

a. Kisi-kisi soal hasil belajar pada bahan ajar bahan ajar Program Linear berbasis kontekstual dan ICT.

b. Pedoman penskoran setiap butir soal hasil belajar

c. Kunci Jawaban setiap butir soal hasil belajar.

2. Pemilihan media (media selection) Media yang dipilih yaitu media berbasis ICT yang bertujuan untuk memudahkan dalam proses pembelajaran, dikarenakan media berbasis ICT sangat relevan pada saat ini. Berdasarkan analisis Pemilihan media (media selection) diperoleh bahwa media yang sangat mendukung dan memungkinkan pada bahan ajar Program Linear berbasis kontekstual dan ICT adalah Microsoft Power point.

3. Pemilihan format (format selection)

Pemilihan format dalam pengembangan perangkat pembelajaran ini dimaksudkan untuk mendesain atau merancang isi pembelajaran. Dalam hal ini format yang dikembangkan yaitu berbasis kontekstual.

4. Rancangan awal (initial design)

Berdasarkan analisis yang telah dilakukan diperoleh rancangan awal draft I yaitu rancangan seluruh perangkat pembelajaran yaitu bahan ajar dan media yang harus dikerjakan sebelum ujicoba dilaksanakan.

\section{Tahap III: Develop (Pengembangan)}

Data hasil pengembangan bahan ajar Tahap III disajikan pada Tabel 1 berikut:

Tabel 1 Hasil Data Validasi Desain Ahli

\begin{tabular}{|c|c|c|c|c|}
\hline No & Ahli & Jumlah & $\begin{array}{c}\text { Rata-rata } \\
\left(\boldsymbol{R}_{\boldsymbol{i}}\right)\end{array}$ & Kriteria \\
\hline 1 & $\begin{array}{c}\text { Ahli } \\
1\end{array}$ & 141 & 3,81 & Valid \\
\hline 2 & $\begin{array}{c}\text { Ahli } \\
2\end{array}$ & 175 & 4,72 & $\begin{array}{c}\text { Sangat } \\
\text { Valid }\end{array}$ \\
\hline 3 & $\begin{array}{c}\text { Ahli } \\
3\end{array}$ & 132 & 3,57 & Valid \\
\hline \multicolumn{3}{|c|}{$\begin{array}{c}\text { Rata-rata ketiga } \\
\text { Validasi Ahli }\end{array}$} & 4,04 & \\
\hline \multicolumn{3}{|c|}{$\begin{array}{c}\text { Kriteria ketiga Ahli } \\
\text { Sangat } \\
\text { Valid }\end{array}$} \\
\hline
\end{tabular}

Berdasarkan Tabel 1 di atas merupakan hasil validasi bahan ajar dari ketiga validator diperoleh kesimpulan bahwa rata-rata hasil validasi tersebut yaitu 4,04 dari skala 5. Dari hasil tersebut disimpulkan bahwa bahan ajar berbasis kontekstual dan ICT ini sangat valid.

Penilaian peserta didik dalam kelompok kecil terhadap bahan ajar berbasis kontekstual dan ICT disajikan dalam Tabel 2 berikut:

Tabel 2 Rangkuman Hasil Uji Coba Kepraktisan

\begin{tabular}{|c|c|c|c|}
\hline $\begin{array}{l}\text { Peserta } \\
\text { Didik }\end{array}$ & Jumlah & Rata-rata & Kriteria \\
\hline 1 & 70 & 3,5 & Baik \\
\hline 2 & 81 & 4,05 & $\begin{array}{c}\text { Sangat } \\
\text { Baik }\end{array}$ \\
\hline 3 & 78 & 3,9 & Baik \\
\hline 4 & 69 & 3,45 & Baik \\
\hline 5 & 76 & 3,8 & Baik \\
\hline \multicolumn{2}{|c|}{ Rata-rata } & $\mathbf{3 , 7 4}$ & Baik \\
\hline \multicolumn{4}{|c|}{ Kriteria Dari penilaian hasil ujicoba } \\
\hline \multicolumn{4}{|c|}{ Dari }
\end{tabular}

kepraktisan produk yang dilakukan pada 5 siswa diperoleh rata-rata nilai sebesar 3,74 dari skala 5. Dari nilai tersebut dapat disimpulkan bahwa kepraktisan bahan ajar berbasis kontekstual dan ICT tersebut tergolong kriteria baik, 
sehingga bahan ajar berbasis ICT ini baik untuk digunakan dalam proses pembelajaran.

Setelah dilakukan uji prasyarat menggunakan uji normalitas dan uji homogenitas, langkah selanjutnya adalah menguji hipotesis menggunakan uji-t. Uji ini bertujuan untuk mengetahui perbedaan rataan pretes dan postes. Berdasarkan hasil uji normalitas dan homogenitas bahwa data kedua kelas berdistribusi normal dan varians kedua kelas homogen, maka bisa dilanjutkan pada uji perbedaan rataan pretes dan postes menggunakan paired sample t-test.

Hasil uji rataan pretes dan rataan postes tersebut diketahui bahwa nilai Sig. (1-tailed) yaitu 0,00 lebih kecil dari nilai $\alpha=0,05$, sehingga $\mathrm{H}_{0}$ ditolak. Hasil ini berarti kedua kelas memiliki hasil belajar yang berbeda secara signifikan, sehingga dapat disimpulkan bahwa ada pengaruh yang sangat signifikan penggunaan bahan ajar berbasis kontekstual dan ICT terhadap hasil belajar. Dengan kata lain, bahan ajar berbasis kontekstual dan ICT tersebut sangat efektif untuk digunakan dalam proses pembelajaran

\section{Tahap IV: Disseminate (Penyebaran)}

Proses diseminasi merupakan suatu tahap akhir pengembangan. Tahap diseminasi dilakukan untuk mempromosikan produk pengembangan agar bisa diterima pengguna, baik individu, suatu kelompok, atau sistem. Pada tahap penyebaran ini dilakukan dengan cara membagikan bahan ajar dan media ICT ke beberapa sekolah untuk mendapatkan masukan akhir sebelum disebar dalam skala yang lebih besar lagi. Setelah itu produk yang dihasilkan akan di-publish di internet. Selain itu produk yang dihasilkan juga akan diseminarkan pada seminar nasional, dengan harapan produk tersebut dapat tersebar secara nasional.

\section{KESIMPULAN DAN SARAN}

Berdasarkan pengembangan bahan ajar berbasis kontekstual dan ICT diperoleh hasil hasil validasi bahan ajar dari ketiga validator diperoleh bahwa rata-rata hasil validasi tersebut yaitu 4,04 dari skala 5, hasil tersebut disimpulkan bahwa bahan ajar berbasis kontekstual dan ICT ini sangat valid. Selanjutnya, dari penilaian hasil uji coba kepraktisan produk yang dilakukan diperoleh rata-rata nilai sebesar 3,74 dari skala 5, sehingga dapat disimpulkan bahwa kepraktisan bahan ajar berbasis kontekstual dan ICT tersebut tergolong kriteria baik.

Pada tahap pengembangan untuk mengetahui efektivitas bahan ajar berbasis kontekstual dan ICT, diperoleh hasil analisis data diperoleh nilai Sig. = 0.000 dimana nilai $\alpha=0.05$, karena nilai Sig. $<\alpha$ sehingga dapat disimpulkan bahwa ada pengaruh yang sangat signifikan penggunaan bahan ajar berbasis kontekstual dan ICT terhadap hasil belajar. Dengan kata lain, bahan ajar berbasis kontekstual dan ICT tersebut sangat efektif untuk digunakan dalam pembelajaran pada materi program linear.

Berdasarkan hasil penelitian yang diperoleh, maka saran yang sekiranya dapat diberikan peneliti sebagai bahan pertimbangan untuk perbaikan adalah sebagai berikut:

1. Bahan ajar berbasis kontekstual dan ICT agar dapat digunakan pada pembelajaran dengan waktu yang maksimal agar hasil yang dicapai menjadi lebih optimal.

2. Guru harus terbiasa menggunakan bahan ajar berbasis kontekstual dan ICT agar guru mampu menguasai materi, sehingga pembelajaran 
menggunakan bahan ajar berbasis kontekstual dan ICT dapat berjalan dengan baik.

3. Perlu diadakan pengembangan lebih lanjut terhadap bahan ajar menulis petunjuk dengan pendekatan kontekstual untuk melengkapi kekurangan pada bahan ajar tersebut.

4. Bahan ajar yang telah dikembangkan diproduksi secara masal dan disebarkan pada pengguna yang lebih luas, sehingga keterbacaan menjadi lebih luas juga.

\section{DAFTAR PUSTAKA}

Baharuddin dan Wahyuni, E. N. (2008). Teori Belajar dan Pembelajaran. Jogjakarta: ArRuzz Media Group

Darmadi, H. (2009). Kemampuan Dasar Mengajar (Landasan Konsep dan Implementasi). Bandung: Alfabeta.

Korucu, A.T. dan Gunduz, S. (2011). The effects of computer assisted instruction practices in computer office program course on academic achievements and attitudes toward computer. The Journal of Procedia Social and Behavioral Sciences 15: Elsevier, p.1931-1935.

Mudlofir, A. (2011). Aplikasi Pengembangan Kurikulum Tingkat Satuan Pendidikan dan Bahan Ajar. Jakarta: Raja Grafindo Persada

Thiagarajan, S., Semmel, D. S dan Semmel, M. I. (1974). Instructional Development for Training Teachers of
Exceptional Children: A Sourcebook. Minneapolis, Minnesota: Leadership Training Institute/Special Education, University of Minnesota. 